\title{
The determinants of purchase intention of consumers towards counterfeit shoes in Pakistan
}

\author{
Muhammad Waqas Tariq Chaudary \\ Research Scholar, Department of Management Sciences, \\ The Islamia University of Bahawalpur, Pakistan \\ E-mail: waqastariq72@gmail.com
}

\author{
Furqan Ahmed \\ Research Scholar, Department of Management Sciences, \\ The Islamia University of Bahawalpur, Pakistan \\ E-mail: furqanahmed20dnb@gmail.com
}

\begin{abstract}
Muhammad Sajid Gill
Research Scholar, Department of Management Sciences,

The Islamia University of Bahawalpur, Pakistan

E-mail: sajidgill_38@yahoo.com

Muhammad Rizwan

Lecturer, Department of Management Sciences

The Islamia University of Bahawalpur, Pakistan

E-mail: rizwan.arshad@iub.edu.pk
\end{abstract}

Accepted: July 01, 2014

Doi:10.5296/jpag.v4i3.5847 URL: http://dx.doi.org/10.5296/jpag.v4i3.5847

\begin{abstract}
Purpose - The purpose of this study is to understand the factors that influence attitude and purchase intention of the consumers towards buying counterfeits especially the counterfeit shoes. Particularly we are interested in the factors; attitude, value consciousness, social status, low price, easy access and previous experience.
\end{abstract}


Design/Methodology/Approach- Total 180 participants out of 200 completed the questionnaire that contained two sections. Section I contained 5 questions for data collection regarding demographics of the participants, Section II contained 24 different statements related to purchase intention, attitude towards buying counterfeit shoes, value consciousness, low price, social status and past experience. The data was analyzed using linear regression.

Findings - Low Price, Easy Access and Past Experience have a Positive significant relationship with Attitude towards Buying Counterfeit Shoes, while Value Consciousness (negative) and Social Status found an insignificant relationship with Attitude towards Buying Counterfeit Shoes. Attitude towards Buying Counterfeit Shoes explains a considerable percentage of the variance of intention to purchase counterfeits Shoes. Low Price and Past Experience found a positive significant relation with Purchase intention while Easy Access found (negative) an insignificant relation with purchase intention.

Research Limitations - A more appropriate and effective method will be the data collection from the individuals doing shopping in the shopping malls and other shoes shops. Ethical and moral values influenced by culture, nationality and other such factors may be included. Future research should examine attitude and purchase intention of consumers in regards of T-shirt, Dress Shirts and Jeans.

Originality/Value - A specific high usage consumer item, one of the basic needs of people; studied as opposed to previous studies only examining Counterfeit Mobile phones.

Keywords: Counterfeit Shoes, Attitude towards Buying Counterfeit Shoes, Counterfeiting

\section{Introduction}

The alarming emergence of global economic phenomenon of counterfeiting and the lack of research work in the context of consumer purchase intentions towards counterfeits makes the study more worthwhile than ever before. Counterfeits are defined as reproduced copies that are identical to the legitimate articles including packaging, labeling and trademarks (Kay, 1990). Counterfeiting has existed for a long time (Clunas, 1991), yet the issue has only been a serious concern for legitimate manufacturers since the 1970s (Harvey and Ronkainen, 1985). Product counterfeiting and piracy of either luxury consumer or industrial goods is a severe global problem and is prevailing more in developing countries than in developed nations. The fact is that the consumers only perceive the social benefits of fake products, they do not bother that their behavior is harmful to a specific industry or that it can lead to a social cost (Lysonski and Durvasula, 2008).

Counterfeiting is categorized in different forms as deceptive, non-deceptive and blurs counterfeiting (Grossman and Shapiro, 1988; Bian, 2006). Through deceptive and blur counterfeiting consumers are either not conscious or uncertain of facts that he/she is purchasing counterfeits, while Consumers purposely purchasing counterfeits is named as purchase non-deceptive counterfeits (Grossman and Shapiro, 1988).

Counterfeits become a serious threat to genuine and legitimate industries especially when 
consumers knowingly buy them. According to The Organization of Economic Cooperation and Development's (OECD) the growth rate of counterfeiting and piracy business is 15\% annually. If some appropriate measures are not taken, it will increase its value up to $\$ 960 \mathrm{bn}$. by 2015 (Frontier Economics, Feb 2011).

Despite the fact that manufacturing and selling counterfeits are considered to be crimes in some countries, for example, the US and the UK (Hopkins et al., 2003; Bush et al., 1989), past studies suggest that about one-third of consumers go for purchase of non-deceptive counterfeits (e.g. Phau et al., 2001; Tom et al., 1998) no matter what would be its consequences. China is the main producer of counterfeits and pirated products in the world. Counterfeit manufacturers, especially in developing economies, get attracted to the business as they find little risk in return for a high rewards. Slow judiciary processes, loopholes in laws and its enforcement, and low conviction rates and penalties (if any) allow counterfeiters to emerge and thrive (Bush et al., 1989; Wee et al., 1995; Chaudhury and Walsh, 1996; Cordell et al., 1996). Hence, both the economic development level and the level of corruption have been linked to areas with increased levels of counterfeiting (Santos and Ribeiro, 2006). The key sources of counterfeits are Russia, Argentina, Chile, Egypt, India, Israel, Lebanon, Thailand, Turkey, Ukraine, Venezuela, Brazil, Paraguay and Mexico after China. USA is the major consumer of counterfeits with little home production (Chaudhry and Zimmerman, 2009).

Actions to control counterfeits can arise from both supply and demand side, considering the tricks, companies employ to deter counterfeits (Chaudhry et al., 2005) and the motivation that make a counterfeit an interesting choice for some customers (Huang et al., 2004; Ang et al., 2001).

The purpose of this study is to understand the factors that influence attitude and purchase intention of the consumers towards buying counterfeits especially the counterfeit shoes. Particularly we are interested in the factors; attitude, value consciousness, social status, low price, easy access and previous experience.

Attitude is an "instructed tendency to retort a situation in an advantageous or disadvantageous mode" (Huang et al. 2004). Researchers trust on exploring consumer attitudes through research standards, as attitude cannot be ascertained directly (Huang et al. 2004). Realizing, Attitude is significant as it determines consumer behavior directly. An attitude towards an item is an intimate assessment based on their opinions by persons (Fishbein and Ajzen, 1975). It determines persons' intentions that affect their behaviors successively (Ajzen and Fishbein, 1980).

Value consciousness has been defined as an interest for yielding lower prices, depending on some quality shortcoming (Ang et al. 2001) and has been found to have a sure impact on attitude towards imitated goods (Bloch et al. 1993, Ang et al. 2001, Wang et al. 2005).

Social status according to Eastman et al. (1999, p. 42) is "the motivational process by which individuals strive to improve their social status through conspicuous consumption of consumer products that symbolize status for both individuals and surrounding others". There 
is no surprise that the willingness to purchase counterfeits is associated with social status, as branded products help consumers to communicate an status picture to those who surround them. Prior research indicates that consumers who purchase counterfeits believe they obtain the prestige credited to the real product (Bloch et al., 1993; Ang et al., 2001).

Several studies illustrated that low price is a vital causal factor influencing demand for fake goods (Dodge et al. 1996; Albers Miller, 1999; Prendergast et al. 2002; Harvey and Walls, 2003). Buyers wish to purchase original goods but just few of them can get them. Consumers who cannot buy genuine brands, the high priced actual brands provide a opportunity to low priced counterfeits to fulfill their demand (Chuchinprakarnm, 2003; Chaudhry et al. 2009).

Easy availability of counterfeits and fake products motivate consumers to buy them (Penz and Stottinger, 2005; Stumpf et al., 2011; Rizwan et al., 2013). Counterfeits, especially non-deceptive counterfeits, are available at the places which are visited by the consumers frequently.

Based on the assumption that consumer behavior is the result of learning (Bentlar and Speckart, 1979), there is an argument among the researchers that consumers' past behavior may provide improved predictions of behavioral intentions (Corner and Armitage, 1998). Delgado-Ballester and Munuera-Aleman (2005) established that the trust developed through past experience becomes an important part of current purchase and prove the customer as loyal moreover serves as brand equity in future.

\section{Literature Review}

\section{Attitude towards buying counterfeits}

Having an understanding about the attitude is important as it directly influences consumer behavior. An attitude towards an object is an internal evaluation by individuals based on their beliefs (Fishbein and Ajzen, 1975). It influences individuals' intentions which in result affect their behaviors (Ajzen and Fishbein, 1980). According to Aaker et al. (1995) attitude is the mental state individuals use to structure the ways to perceive the environment. It also guides them how to respond to their surroundings and environment. It can be either positive or negative. An individual may have positive attitude towards legally and ethically unwanted products. De Matos et al. (2007) found that some buyers have positive attitude towards counterfeits while some judged them negatively. Consumers' positive attitude towards counterfeits is positively associated with their purchase intentions; especially it is witnessed in cases of counterfeited products.

H1: Attitude towards buying counterfeits shoes has positive influence on the consumers' purchase intention of buying counterfeit shoes

\section{Value Consciousness}

Value consciousness has been defined as a concern for paying lower prices, subject to some quality constraint (Ang et al., 2001) and has been found to have a positive influence on 
attitude towards pirated products (Ang et al., 2001; Wang et al., 2005; Bloch et al., 1993). Ang et al. (2001) argued that typical counterfeit consumers are more value conscious, and have lower average income compared to those who do not purchase counterfeit products. Similarly, Bloch et al. (1993) found that counterfeit buyers have low purchasing power and are therefore driven by the price/value perception. Since counterfeits of luxury brands usually provide the same functional benefits as the original, but at a fraction of the price of the genuine product, they are perceived favorably. Thus, for consumers who are value conscious, "good value" of counterfeit products encourages them to purchase (Eisend and Schuchert-Guller, 2006).

H2: Consumers' value consciousness positively affects consumers' attitude towards buying counterfeit shoes.

\section{Social Status}

Social status according to Eastman et al. (1999, p. 42) is "the motivational process by which individuals strive to improve their social standing through conspicuous consumption of consumer products that confer or symbolize status for both individuals and surrounding others". Since branded products help consumers to communicate an image to those who surround them, there is no surprise that the willingness to purchase counterfeits is associated with social status. Previous researches indicate that consumers who purchase counterfeits believe they obtain the prestige ascribed to the real product (Bloch et al., 1993; Ang et al., 2001).

A more recent study reinforces the phenomenon that counterfeited brands are bought for what they represent in the buyer's social environment. Wilcox et al. (2009) findings explain that the attitude toward luxury brands predicts the intention to buy counterfeit products, thus supporting the expectation that consumers respond more favorably to image appeals when such appeal is consistent with their social goal of projecting a particular image in social settings. Another study conducted in a European Union country, reports on 127 interviews about the perception of original and counterfeit brands (Penz and Stottinger, 2008). Both original brands and counterfeits are considered to enhance consumers' self-esteem and promote a certain status within a peer group (Penz and Stottinger, 2008).

H3: The more people search for social status, the more positive the attitude towards buying counterfeit shoes.

\section{Low Price}

Several re-searches found that low price is an important factor stimulating demand for counterfeit products (Dodge et al., 1996; AlbersMiller, 1999, Prendergast et al., 2002; Harvey and Walls, 2003). Consumers want to buy genuine products but only some of them can afford them. The high priced original brands provide an opportunity to low priced counterfeits to meet the needs of those who cannot afford original brands (Chuchinprakarnm, 2003, 


\section{MInstitute ${ }_{\text {Mnk }}^{\text {Macrothin }}$}

Chaudhry et al., 2009). Deceptive counterfeits' low price has been witnessed to stimulate demand for non- deceptive counterfeits (Staake and Fleisch, 2008). Consumers recognize non-deceptive counterfeited products by their low price and buying location (Prendergast et al., 2002). Consumers from the USA and Brazil believe that people purchase counterfeited products because of their low income level and low literacy level and awareness (Stumpf et al., 2011). Consumers prefer counterfeits over original brands especially when counterfeits are distinctly available at lower prices (Bloch et al., 1993; Gentry, 2006; Ergin, 2010). Furthermore, some consumers desire to adopt affluent lifestyles but are not financially sound to buy original brands and hence they go for counterfeits (Gistri et al., 2009). Similarly, price conscious consumers willing to buy counterfeits as these are cost effective (Haque et al., 2009; Gino, 2010; Rizwan et al., 2013).

H4: Low price positively affects the consumers' attitude towards buying counterfeit shoes.

H5: Low price directly positively influences the consumers' Purchase intention of buying counterfeit shoes.

\section{Easy Access}

Easy availability of counterfeits and pirated products motivate consumers to buy them (Penz and Stottinger, 2005; Stumpf et al., 2011). Counterfeits, especially non-deceptive products, are available at such places which consumers frequently visit. They are mostly sold at open markets and at street vendors (OECD, 2008). Counterfeits are normally sold through 3 distribution outlets: "established retail shops"; informal channels such as "flea markets", "side walk vendors", "clandestine shops" and Internet. Some deceptive counterfeit products may be found at supermarket shops as retailers are mostly unaware about the illegal nature of these deceptive counterfeits (Chaudhry et al., 2009). The lengthy supply chain of counterfeited products enhances purchase intentions for high spenders than low spender (e.g., in case of VCDs) (Prendergast et al., 2002). The level of availability and ease of access influence the demand for both counterfeits and pirated products. But this situation may vary at different markets. Nowadays, the chances to buy counterfeits at open markets are higher than at regulated markets (Lee and Yoo, 2009).

H6: Easy access positively affects the consumers' attitude towards buying counterfeit shoes.

H7: Easy access directly positively influences the consumers' Purchase intention of buying counterfeit shoes.

\section{Previous Experience}

Based on the assumption that consumer behavior is the result of learning (Bentlar and Speckart, 1979), there is an argument among the researchers that consumers' past behavior can provide improved predictions of behavioral intentions (Corner and Armitage, 1998). Delgado-Ballester and Munuera-Aleman (2005) established that the trust developed through 


\section{Macrothink}

past experience becomes a vital part of current purchase and name the customer as loyal moreover serves as brand equity in future. Ang et al. (2001) found counterfeit buyers different from non-buyers, the former take such purchases less risky, not viewing this purchase as unethical and trusting the stores for prior counterfeit purchase. Research has found counterfeit buyers poles apart from-non buyers and past experience to enhance attitudes (i.e. have more positive attitude) towards counterfeit products (Tom et al. 1998; Wang et al. 2005). Majority of consumers who had never bought counterfeit product did not choose counterfeit items, they also did not express any positive intention to buy counterfeit product in future when they were offered the opportunity to purchase the counterfeits.

H8: Past Experience positively influences the consumer's attitude towards buying counterfeit shoes.

H9: Past Experience positively influences the consumers' purchase intention of buying counterfeit shoes

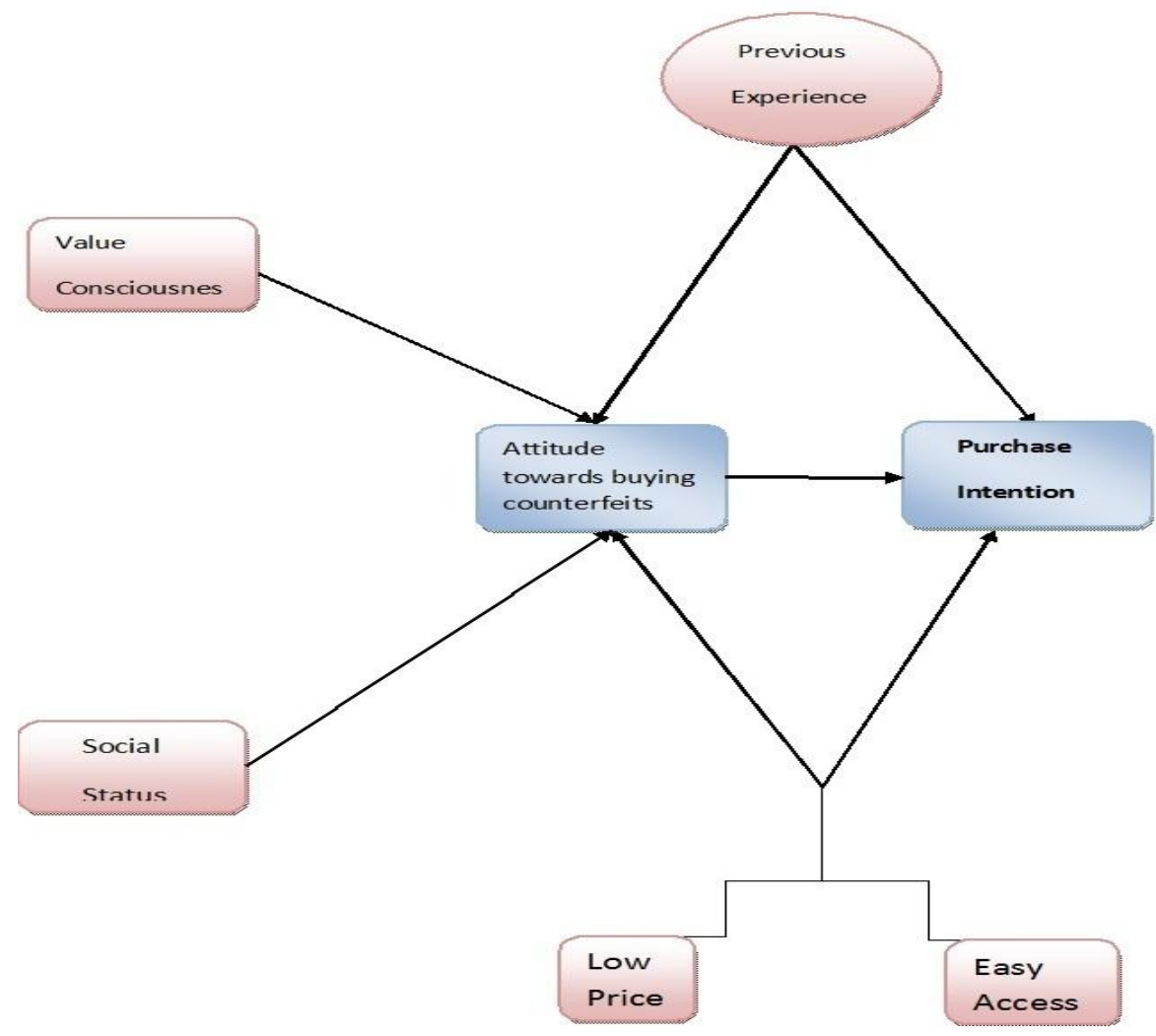

\section{Conceptual Research Model}

\section{Research Methodology}

According to the nature this research falls in the category of Descriptive Research. It can be explained as describing something, some idea, some phenomenon or any particular situation. 


\section{Macrothink}

Descriptive researches are the researches which describe the prevailing situation instead of interpreting and making judgments (Creswell, 1994). The verification of the developed hypotheses that reflect the current situation is the main purpose of the descriptive research. Along with that this sort of research also provides information about the current study scenario and focus on past or present.

\section{Sample Data}

For the collection of data for the understanding the factors affecting the attitude and purchase intention of the consumers towards buying counterfeit shoes, a sample of 200 respondents will ask to participate in a self-administered questionnaire. The population for this research is the ultimate consumers in Pakistan.

Non-probability sampling technique is utilized in this study, which is convenience sampling. Convenience sampling is a sampling technique that obtains and collects the relevant information from the sample that is conveniently available (Zikmund, 1997).

\section{Instrument and Measures}

The survey instrument of the study was a self administered questionnaire. The purpose of this survey instrument is to make an analysis of relationship of different variables with the Attitude and Purchase Intention towards Buying Counterfeit Shoes.

The questionnaire comprises of two sections. Section 1 includes different personal and demographic variables. This section will gather the respondent's information about gender, age, income, education and status, while Section 2 includes the different variables important in the current study. These variables include Purchase Intention, Attitude towards Buying Counterfeit Shoes, Value Consciousness, Past Experience, Low Price, Easy Access and Social Status.

The scales of the study were adopted from the previous literature and published studies. The first two variables were Purchase intention and Attitude towards Buying Counterfeit Shoes. Each variable have three items and these scales were taken from De Matos et al. (2007). The next variable Value Consciousness comprises of three items, scales of which were taken from Lichetenstein et al. (1993). The next two variables were Past Experience and Low price having three and five items respectively. Scales were taken from Tom et al. (1998). The next variable was Easy Access having four items and the scale were taken from Lee and Workman (2011), Yoo and Lee (2009), de Matos et al. (2007). The last variable was Social Status comprised of three items and the scales for that variable items were taken from Lassar et al. (1995) Eastman et al. (1999). 
Table 1: Scales of Study

\begin{tabular}{|c|c|c|c|}
\hline Sr.\# & Variables & Items & Reference \\
\hline 1 & $\begin{array}{l}\text { Purchase } \\
\text { Intention }\end{array}$ & $\begin{array}{l}\text { 1. I would intend to buy counterfeit shoes. } \\
\text { 2. I am likely to purchase any counterfeit shoes. } \\
\text { 3. I have a high intention to buy counterfeit shoes. }\end{array}$ & $\begin{array}{l}\text { De Matos et } \\
\text { al. }(2007\end{array}$ \\
\hline 2 & $\begin{array}{l}\text { Attitude } \\
\text { towards } \\
\text { buying } \\
\text { counterfeit } \\
\text { shoes }\end{array}$ & $\begin{array}{l}\text { 1. Counterfeit shoes generally benefit the consumers. } \\
\text { 2. There is nothing wrong with purchasing counterfeit } \\
\text { shoes. } \\
\text { 3. Generally speaking, buying counterfeit shoes is a } \\
\text { better choice. }\end{array}$ & $\begin{array}{l}\text { De Matos et } \\
\text { al. (2007) }\end{array}$ \\
\hline 3 & $\begin{array}{l}\text { Value } \\
\text { Consciousness }\end{array}$ & $\begin{array}{l}\text { 1. I am very concerned about low price, but I am equally } \\
\text { concerned about high quality. } \\
\text { 2. When purchasing a counterfeit shoes, I always try to } \\
\text { maximize the } \\
\text { quality I get for money I spend } \\
\text { 3. I generally shop around for lower prices on } \\
\text { counterfeit shoes, but } \\
\text { they still must meet certain quality requirements } \\
\text { before I will buy } \\
\text { them. }\end{array}$ & $\begin{array}{l}\text { Lichetenstein } \\
\text { et al. (1993) }\end{array}$ \\
\hline 4 & $\begin{array}{l}\text { Past } \\
\text { Experience }\end{array}$ & $\begin{array}{l}\text { 1. I have bought counterfeit shoes in the past. } \\
2 \text {. I am intended to buy counterfeit shoes in } \\
\text { the future as well. } \\
\quad 3 . \quad \text { I found counterfeit shoes a better } \\
\text { choice to have in the past. }\end{array}$ & $\begin{array}{l}\text { Tom et al. } \\
\text { (1998). }\end{array}$ \\
\hline
\end{tabular}




\begin{tabular}{|c|c|c|c|}
\hline 5 & Low price & $\begin{array}{l}\text { 1. I usually purchase the least expensive counterfeit } \\
\text { shoes } \\
\text { 2. I often find myself checking prices. } \\
\text { 3. I am always attracted towards low price shoes. } \\
\text { 4. The low price of counterfeit shoes is appealing to me. } \\
\text { 5. I buy counterfeit shoes because the prices of genuine } \\
\text { brands are unfair. }\end{array}$ & $\begin{array}{l}\text { Tom et al. } \\
\text { (1998). }\end{array}$ \\
\hline 6 & Easy Access & $\begin{array}{l}\text { 1. I don't need to make much effort to buy a } \\
\text { non-deceptive counterfeit } \\
\text { Shoes } \\
\text { 2. Non-deceptive counterfeit shoes are available in my } \\
\text { local area } \\
\text { 3. In every shoes shop non-deceptive counterfeit shoes } \\
\text { are available. } \\
\text { 4. There is no legal problem in obtaining non-deceptive } \\
\text { counterfeit } \\
\text { shoes. }\end{array}$ & $\begin{array}{l}\text { Lee and } \\
\text { Workman } \\
(2011), \quad \text { Yoo } \\
\text { and Lee } \\
(2009), \quad \text { de } \\
\text { Matos et al. } \\
(2007) .\end{array}$ \\
\hline 7 & Social Status & $\begin{array}{l}\text { 1. I would be proud to own a counterfeit of branded shoes } \\
\text { 2. I would buy a counterfeit of branded shoes just because } \\
\text { it has status } \\
\text { 3. I would pay more for a counterfeit of branded shoes if it } \\
\text { had status }\end{array}$ & $\begin{array}{l}\text { Lassar et al. } \\
(1995) \\
\text { Eastman et } \\
\text { al. (1999) }\end{array}$ \\
\hline
\end{tabular}




\section{Macrothink}

\section{Procedure}

The survey instrument was distributed among 200 respondents in Bahawalpur. More than $95 \%$ of respondents were related with the education sector belonging to The Islamia University of Bahawalpur. These respondents were selected upon the basis of criteria above mentioned. The purpose of study and the questions regarding different variables were explained to the respondents before giving the questionnaire. Out of 200 questionnaires 180 were selected and the remaining was not included in the further analysis because of incomplete and invalid responses. These questionnaires were then coded and entered in to SPSS sheet for analysis.

\section{Reliability Analysis:}

Chronbach's Alpha of Attitude and Purchase Intention of Consumers towards Buying Counterfeit Shoes questionnaire items is more than recommended and acceptable value 0.50 by Nunnally (1970) and 0.6 by Moss et al. (1998). This shows that all 24 items were reliable and valid to measure the opinions of consumers' attitude and purchase intention towards buying counterfeit shoes.

Table 2: Reliability of Measurements Instrument

\begin{tabular}{|l|l|l|}
\hline Scales & Items & Cronbach Alpha \\
\hline Purchase Intention & 3 & 0.840 \\
$\begin{array}{l}\text { Attitude towards buying counterfeit } \\
\text { shoes }\end{array}$ & 3 & 0.723 \\
Value Consciousness & 3 & 0.616 \\
Past Experience & 5 & 0.704 \\
Low Price & 4 & 0.627 \\
Easy Access & 3 & 0.700 \\
Social Status & & 0.676 \\
\hline
\end{tabular}




\section{Macrothink

\section{Results \& Analysis:}

\section{Profile of Respondents}

Demographic and Personal information such as gender, age, income, education and status level are presented in the following table.

Table 3: Profile of Respondents

\begin{tabular}{|c|c|c|c|}
\hline & Category & Frequency & Percentage \\
\hline Variable & & & \\
\hline Gender & $\begin{array}{l}\text { Male } \\
\text { Female }\end{array}$ & $\begin{array}{l}81 \\
99\end{array}$ & $\begin{array}{l}45 \\
55\end{array}$ \\
\hline Age & $\begin{array}{l}\text { 15-20 Years } \\
\text { 20-25 Years } \\
\text { 25-30 Years } \\
\text { 30-35 Years } \\
\text { 35-40 Years } \\
\text { Above } 40 \text { Years }\end{array}$ & $\begin{array}{l}85 \\
80 \\
3 \\
9 \\
3 \\
0\end{array}$ & $\begin{array}{l}47.2 \\
44.4 \\
1.7 \\
5.0 \\
1.7 \\
0\end{array}$ \\
\hline Income & $\begin{array}{l}\text { Below } 15000 \\
15000-25000 \\
25000-35000 \\
35000-45000 \\
45000-55000 \\
\text { Above } 50000\end{array}$ & $\begin{array}{l}64 \\
42 \\
15 \\
24 \\
9 \\
26\end{array}$ & $\begin{array}{l}35.6 \\
23.3 \\
8.3 \\
13.3 \\
5.0 \\
14.4\end{array}$ \\
\hline Education & $\begin{array}{l}\text { Matriculation } \\
\text { Inter } \\
\text { Bachelor } \\
\text { Master } \\
\text { MS/ M.Phil } \\
\text { PHD }\end{array}$ & $\begin{array}{l}5 \\
15 \\
97 \\
48 \\
11 \\
4\end{array}$ & $\begin{array}{l}2.8 \\
8.3 \\
53.9 \\
26.7 \\
6.1 \\
2.2\end{array}$ \\
\hline
\end{tabular}




\begin{tabular}{|l|l|l|l|}
\hline Status & Student & 158 & 87.8 \\
Employed & 15 & 8.3 \\
Businessman & 0 & 0 \\
Unemployed & 6 & 3.3 \\
& Housewife & 1 & 0.6 \\
\hline
\end{tabular}

\section{Hypothesis Testing:}

\section{Attitude towards Buying Counterfeit Shoes, Purchase Intention}

According to outcomes of study, the variable of Attitude towards Buying Counterfeit Shoes have a significant positive relationship with Purchase Intention with $(\beta=0.438)$ and $(\mathrm{p}<$ 0.01). It means the Attitude towards Buying Counterfeit Shoes contribute more than $43 \%$ to Purchase Intention. Thus the results validate H1.

\section{Value Consciousness, Attitude towards Buying Counterfeit Shoes}

While considering the positive significance relationship between Value Consciousness and Attitude towards Buying Counterfeit Shoes, the results of current study shows a negative and insignificant relationship between these two variables with $(\beta=-0.143)$ and $(p>0.05)$. Thus, according to results we reject $\mathbf{H 2}$ and concluded that the study did not find a positive and significant relationship of Value Consciousness and Attitude towards Buying Counterfeit Shoes.

\section{Social Status, Attitude towards Buying Counterfeit Shoes}

Regression results show that the Social Status found to be insignificantly related with the Attitude towards Buying Counterfeit Shoes with $(\beta=0.035)$ and $(p>0.05)$. Thus, based on the results we reject $\mathbf{H 3}$ and conclude that this research find an insignificant relationship between Social Status and Attitude towards Buying Counterfeit Shoes.

\section{Low Price, Attitude towards Buying Counterfeit Shoes}

There found a positive significant relationship between Low price and Attitude towards Buying Counterfeit Shoes with the $(\beta=0.141)$ and $(\mathrm{p}<0.05)$. That means the independent variable Low Price contributes more than 14\% to Attitude towards Buying Counterfeit Shoes. Thus the results of the study support $\mathbf{H 4}$.

\section{Low Price, Purchase Intention}

Regression Analysis of the Attitude and Purchase Intention of the Consumers towards Buying Counterfeit Shoes model shows that there is a significant positive relationship between Low Price and Purchase Intention with $(\beta=0.278)$ and $(p<0.05)$. The results suggest that the 
Low Price contributes almost 28\% to Purchase Intention. Hence, the results support $\mathbf{H 5}$.

\section{Easy Access, Attitude towards Buying Counterfeit Shoes}

According to the regression estimate results the independent variable Easy Access have a significant and positive relationship with Attitude towards Buying Counterfeit Shoes with ( $\beta$ $=0.251)$ and $(\mathrm{p}<0.05)$. So, it means Easy Access contributes more than $25 \%$ to Attitude towards Buying Counterfeit Shoes. Thus the results validate H6.

\section{Easy Access, Purchase Intention}

According to the results of the study, the variable Easy Access found an insignificant and negative relationship with Purchase Intention with $(\beta=-0.038)$ and $(p>0.05)$. So the results of the study rejected $\mathbf{H 7}$ and it is concluded that the study did not find any significant and positive relationship between Easy Access and Purchase Intention.

\section{Past Experience, Attitude towards Buying Counterfeit Shoes}

According to outcomes of study, the variable of Past Experience have a significant positive relationship with Attitude towards Buying Counterfeit Shoes with $(\beta=0.496)$ and $(p<0.01)$. It means the Past Experience more than $49 \%$ to Purchase Intention. Thus the results validate H8.

\section{Past Experience, Purchase Intention}

Regression Analysis of the Attitude and Purchase Intention of the Consumers towards Buying Counterfeit Shoes model shows that there is a significant positive relationship between Past Experience and Purchase Intention with $(\beta=0.267)$ and $(\mathrm{p}<0.05)$. The results suggest that the Past Experience contributes almost $27 \%$ to Purchase Intention. Hence, the results support H9.

Table 4: Regression Results

\begin{tabular}{|c|c|c|c|c|c|c|}
\hline Hypothesis & Model Variables & Estimate & S.E. & C.R. & $\mathbf{P}$ & Results \\
\hline H1 & $\begin{array}{l}\text { Attitude. } \longrightarrow \text { TBCS } \\
\text { PI }\end{array}$ & 0.438 & 0.071 & 6.907 & 0.000 & Supported \\
\hline $\mathrm{H} 2$ & $\begin{array}{l}\text { VC } \longrightarrow \\
\text { Attitude. TBCS }\end{array}$ & -0.143 & 0.064 & -2.488 & 0.14 & Not Supported \\
\hline H3 & $\begin{array}{l}\text { SS } \longrightarrow \\
\text { Attitude. TBCS }\end{array}$ & 0.035 & 0.072 & 0.493 & 0.623 & Not Supported \\
\hline $\mathrm{H} 4$ & $\begin{array}{l}\text { LP } \longrightarrow \\
\text { Attitude. TBCS }\end{array}$ & 0.141 & 0.096 & 1.812 & 0.032 & Supported \\
\hline
\end{tabular}




\begin{tabular}{|l|l|l|l|l|l|l|}
\hline $\mathrm{H} 5$ & $\begin{array}{l}\text { LP } \\
\text { PI }\end{array}$ & 0.278 & 0.075 & 5.100 & 0.000 & Supported \\
\hline $\mathrm{H} 6$ & $\begin{array}{l}\text { EA } \\
\text { Attitude. TBCS }\end{array}$ & 0.251 & 0.101 & 4.174 & 0.000 & Supported \\
\hline $\mathrm{H} 7$ & $\begin{array}{l}\text { EA } \\
\text { PI }\end{array}$ & -0.038 & 0.100 & -0.714 & 0.476 & Not Supported \\
\hline $\mathrm{H} 8$ & $\begin{array}{l}\text { PE } \\
\text { Attitude. TBCS }\end{array}$ & 0.496 & 0.060 & 7.898 & 0.000 & Supported \\
\hline H9 & $\begin{array}{l}\text { PE } \\
\text { PI }\end{array}$ & 0.267 & 0.065 & 4.341 & 0.000 & Supported \\
\hline
\end{tabular}
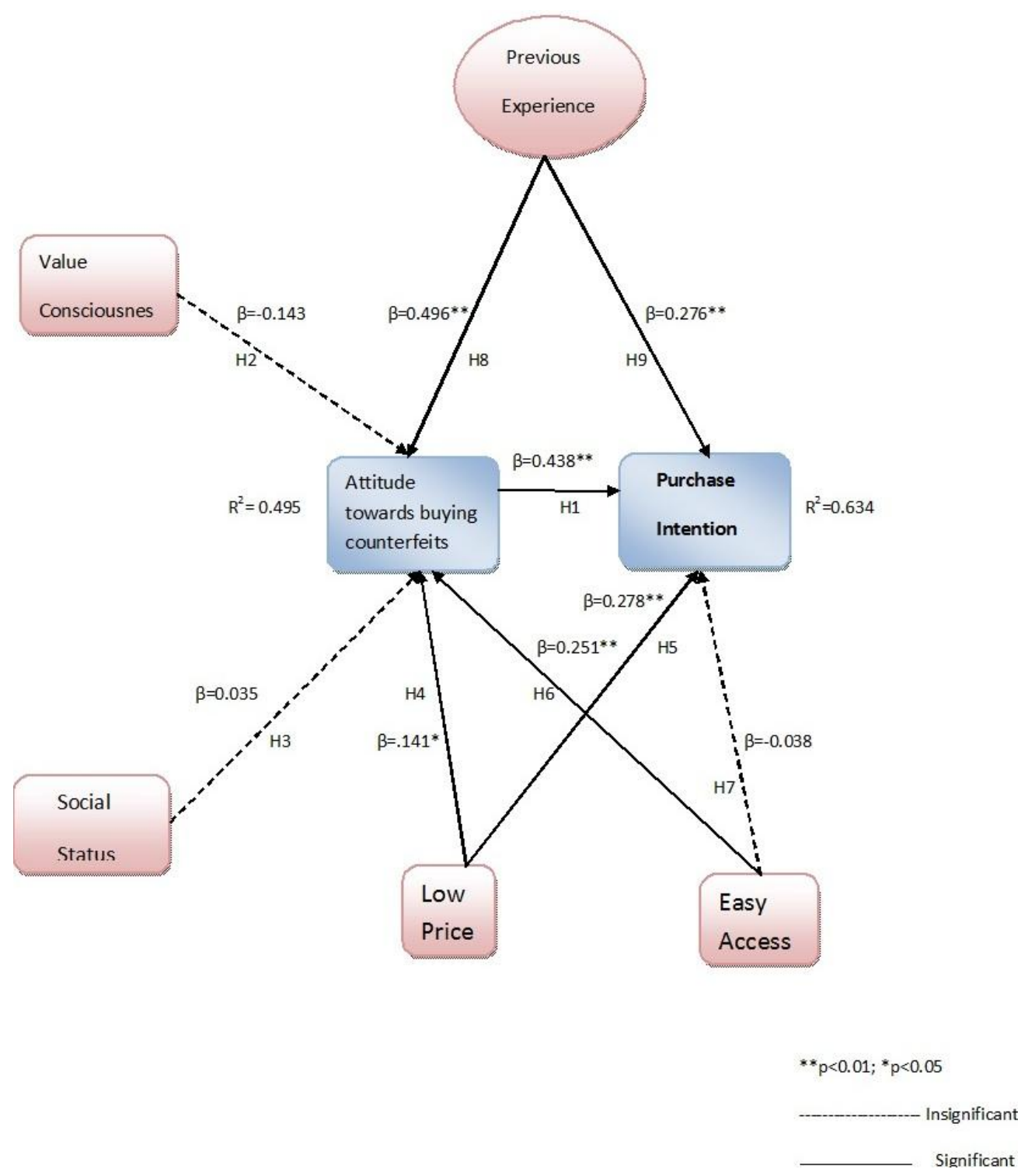


\section{Discussion}

Despite the legal actions taken and bans imposed on counterfeiting trade, it continues to grow rapidly all over the world (Ergin, 2010). Estimates of the OECD show that even if counterfeiting and piracy continues to grow at the rate of $15 \%$ per year its value could grow up to $\$ 960$ bn. by 2015 (Frontier Economics, Feb 2011).

The conceptual model of our study resulted in acceptance of six hypotheses while three hypotheses are not supported by the results. We found that the young consumers' attitude towards buying counterfeit Shoes have significant positive influence on the purchase intentions. It is supported by Yoo and Lee (2009) who found that the consumers ${ }^{\text {ee }}$ positive attitude towards counterfeits influence their purchase intentions positively. The results of our study do not support the influence of value consciousness and social status upon attitude of the consumers towards buying counterfeit shoes; rather we found a negative and insignificant relationship of value consciousness and attitude towards buying counterfeit shoes. While there is an insignificant relationship found between social status and attitude towards buying counterfeit shoes. So, the result is inconsistent with Ang et al. (2001) and De Matos et al. (2007). Low price is also found to have a significant positive relationship with consumers' attitude towards buying counterfeit Shoes. This finding is consistent with previous findings as (Staake and Fleisch, 2008) established "low price motivates consumers to buy non-deceptive counterfeits". Chuchinprakarn (2003) concluded counterfeits are substitutes for these consumers who cannot afford genuine brands. Consumers prefer counterfeits over branded products especially when they are available markedly at lower prices (Bloch et al. 1993; Gentry et al. 2006; Ergin, 2010). Similarly we found a significant positive relationship with consumers' purchase intention. We found that easy access to counterfeit shoes positively affect the young consumers' attitude positively. This finding is inconsistent with the previous studies which found weaker impact of easy access of counterfeits in some context. However, easy access to counterfeit shoes negatively influences the consumers' purchase intentions. Since past experience is proved to have the positive relationship with attitude towards counterfeits, this finding is consistent with Ang et al. (2001) and De Matos et al. (2007). It is established now that consumers who had already bought some counterfeit in past have more favorable attitude towards counterfeits. Similarly we found a positive significant relationship between past experience and consumers' purchase intention.

\section{Limitations and future research}

Since, there is always a space for improvement. There are several limitations in this research worthy of improvement and future study. This study was conducted using mostly the students, teachers and other employees. A more appropriate and effective method will be the data collection from the individuals doing shopping in the shopping malls and other shoes shops, as it will give relatively more accurate and effective picture. Also, this study was restricted to the examination of limited factors that had showed some kind of significant influence on the consumers' attitude and purchase intentions in past studies. Mobile phone deemed to be an item of high product involvement among everyone; other product categories may show different findings. Finally, ethical and moral values influenced by culture, nationality and 
other such factors may be included. New insights may be explored though a cross sectional, cross national and cross cultural study. This study is focused on counterfeit Shoes. Future research should examine attitude and purchase intention of consumers in regards of T-shirt, Dress Shirts and Jeans. A study should also be done to study the reasons of this strange behavior of consumers in Pakistan with reference to low price of counterfeit shoes which is generally assumed to be an important determinant of purchase intention of counterfeit Shoes.

\section{References}

Aaker, A.D. Kumar, V., \& Day, G. (1995). Marketing research. Aaker, A.D., Kumar, V., \& Day, G. (1995). Marketing research.

Albers Miller, N.D. (1999). Consumer misbehavior: Why people buy illicit goods. Journal of Consumer Marketing, 16(3), 27387.

Ang, S.H., Cheng, P.S., Lim, E.A.C. and Tambyah, S.K. (2001), "Spot the difference: consumer responses towards counterfeits", Journal of Consumer Marketing, Vol. 18 No. 3, pp. 219-35.

Ajzen, I., \& Fishbein, M. (1980). Understanding attitudes and predicting social behavior. Englewood Cliffs, NJ: PrenticeHall.

Beverly Hills, CA. Kay, H. (1990), “Fake's progress", Management Today, July, pp. 54-8.

Bentler, P. and Speckart, G. (1979), "Models of attitude-behavior relations", Psychological Review, Vol. 86 No. 5, pp. 452-64.

Bian, X. (2006), "An examination of factors influencing the formation of the consideration set and consumer purchase intention in the context of non-deceptive counterfeiting", University of Glasgow, Glasgow, unpublished $\mathrm{PhD}$ thesis.

Bloch, P. H., Bush, R. F., \& Campbell, L. (1993). Consumer accomplices in product counterfeiting: A demandside investigation. Journal of Consumer Marketing, 10(4), 2736.

Chaudhury, P.E. and Walsh, M.G. (1996), "An assessment of the impact of counterfeiting in international markets: the piracy paradox persists”, Columbia Journal of World Business, Vol. 31, pp. 34-48.

Chaudhry, P. E., \& Zimmerman, A. (2009).The economics of counterfeit trade. Springer Verlag Berlin Heidelberg. Chaudhry, P. E., Zimmerman, A., Peters, J. R., \& Cordell, V. V. (2009). Preserving intellectual property rights: managerial insight into the escalating counterfeit market quandary. Business Horizons, 52(1), 5766.

Chaudhry, P., Cordell, V. and Zimmerman, A. (2005), "Modeling anti-counterfeiting strategies in response to protecting intellectual property rights in a global environment", The Marketing Review, Vol. 5 No. 1, pp. 59-72.

Chuchinprakarn, S. (2003). Consumption of counterfeit goods in Thailand: who are the patrons? European Advances in Consumer Research, 6, 4853.

Clunas, C. (1991), Superfluous Things: Material Culture and Social Status in Early Modern China, University of Illinois Press, Urbana, IL. Cohen, J.B. (1983), "Involvement and you: 1,000 great ideas", Advances in Consumer Research, Vol. 10 No. 1, pp. 325-8.

Conner, M. and Armitage, C. (1998), "Extending the theory of planned behavior: a review and avenues for further research", Journal of Applied Social Psychology, Vol. 28 No. 15, pp. 1429-64.

Cordell, V.V., Wongtada, N., Robert, L. and Kieschnick, J. (1996), "Counterfeit purchase intentions: role of lawfulness attitudes and product traits as determinants", Journal of Business Research, Vol. 35, pp. 41-53. 
De Matos, C.A., Ituassu, T.C., \& Rossi, C. A. V. (2007). Consumer attitudes toward counterfeits: a review and extension. Journal of Consumer Marketing, 24(1), 3647.

Dodge, H.R., Edwards, E.A., \& Fullerton, S. (1996). Consumer transgressions in the marketplace: consumers' perspectives. Psychology and Marketing, 13(8), 821835.

Delgado-Ballester, E. and J. Munuera-Aleman, (2005). Does brand trust matter to brand equity? J. Prod. Brand Management, 14(3): 187-196.

Eastman, J.K., Goldsmith, R.E. and Flynn, L.R. (1999), "Status consumption in consumer behaviour: scale development and validation", Journal of Marketing Theory and Practice, Vol. 7 No. 3, pp. 41-52.

Eisend, M. and Schuchert-Gu "ler, P. (2006), "Explaining counterfeit purchases: a review and preview", Academy of Marketing Science Review, Vol. 2006 No. 12.

Ergin, E.A. (2010). The rise in the sales of counterfeit brands: the case of Turkish consumers. African Journal of Business Management, 4(10), 21812186.

Fishbein, M., \& Ajzen, I. (1975). Belief, attitude, intention and behavior: An introduction to theory and research. Reading, MA: AddisonWesley

Frontier economics (2011). Estimating the global economic and social impacts of counterfeiting and piracy: A report commissioned by business action to stop counterfeiting and piracy (BASCAP). 2011 (February),

Gentry, J. W., Putrevu, S., \& Shultz II, C. J. (2006). The effects of counterfeiting on consumer search. Journal of Consumer Behaviour, 5 (May/June), 245256.

Gino, F., Norton, M. I., \& Dan, A. (2010). The counterfeit self: The deceptive costs of faking it. Psychological Science, 21(5), 712720.

Gistri, G., Simona, R., Stefano, P., Veronica, G., \& Silvia, G. (2009). Consumption practices of counterfeit luxury goods in the Italian context. Brand Management, 16 (March), 364374.

Grossman, G. M., \& Shapiro, C. (1988).Foreign counterfeiting of status goods. Quarterly Journal of Economics, 1(February), 79100.

Haque, A., Khatibi, A., \& Rahman, S. (2009). Factors influencing buying behavior of piracy products and its impact to Malaysian market. International Review of Business Research Papers, 5 (March), 383401.

Harvey, M.G. and Ronkainen, I.A. (1985), "International counterfeiters: marketing success without the cost and the risk", Columbia Journal of World Business, Vol. 20 No. 3, Fall, pp. 37-45.

Harvey, P. J., \& Walls, W. D. (2003). Laboratory markets in counterfeit goods: Hong Kong versus Las Vegas. Applied Economics Letters, 10 (November), 883887

Hopkins, D., Kontnik, L. and Trunage, M. (2003), Counterfeiting Exposed-Protecting Your Brand and Customers,

Huang, J.H., Lee, B.C.Y. and Ho, S.H. (2004), "Consumer attitude toward gray market goods", International Marketing Review, Vol. 21 No. 6, pp. 598-614.

Lichetenstein, D., Ridgway, N. and Netemeyer, R. (1993), "Price perceptions and consumer shopping behavior: a field study", Journal of Marketing Research, Vol. 30 No. 2, pp. 234-45.

Lee, SH., \& Workman, J. E. (2011). Attitudes toward counterfeit purchases and ethical beliefs among Korean and American university students. Family \& Consumer Sciences Research Journal, 39(3), 289305.

Lassar, W., Mittal, B. and Sharma, A. (1995), "Measuring customer-based brand equity", Journal of Consumer Marketing, Vol. 12, pp. 11-19.

Lysonski, S. and Durvasula, S. (2008), "Digital piracy of MP3: consumer and ethical predispositions", Journal of Consumer Marketing, Vol. 25, pp. 167-78. 
Moss, S., Prosser, H., Costello, H. (1998). Reliability and validity of the PAS-ADD

Nunnally, JC. (1970). Introduction to Psychological Measurement. New York: McGraw-Hill

OECD (2008). The economic impact of counterfeiting and piracy.

Penz, E., \& Stottinger, B. (2005). Forget the "real" thing - take the copy: An explanatory model for the volitional purchase of counterfeit products. Advances in Consumer Research, 32, 568575.

Penz, E. and Stottinger, B. (2008), "Original brands and counterfeit brands-do they have anything in common?", Journal of Consumer Behaviour, Vol. 7, pp. 146-63.

Phau, I., Prendergast, G. and Chuen, L.H. (2001), "Profiling brand-piracy-prone consumers: an exploratory study in Hong Kong"s clothing industry", Journal of Fashion Marketing \& Management, Vol. 5, pp. 45-55.

Prendergast, G., Chuen, L H., and Phau, I. (2002). Understanding consumer demand for nondecep tive pirated brands. Marketing Intelligence \& Planning, 20(7): 405416.

Rizwan, M., Khan, H., Saeed, A., Muzaffar, A., Arshad, U. and Hussain, M. (2013) Antecedents of Purchase Intention A Study From Pakistan, IOSR Journal of Business and Management, Vol. 1 (special issue), 58-67

Rizwan, M., Mahar, M. A., Shoukat, N., Javid, R. Z., Khan, G., Bhatti, M. D. \& Khichi, M. M. (2013) Impact of Social Surrounding and sale promotional tools on Customer Purchase Intentions, International Journal of Research in Commerce and Management, 4(3), 156-161

Santos, J.F. and Ribeiro, J.C. (2006), "International counterfeiting in the European Union: a host country approach", Journal of Euromarketing, Vol. 16, pp. 165-76.

Staake, T., \& Fleisch, E. (2008). Countering counterfeit trade: Illicit market insights, best practice strategies, and management toolbox, ISBN: 3540769463, Berlin: Springer.

Stumpf, S.A., Chaudhry, P. E., \& Perretta, L. (2011). Fake: Can business stanch the flow of counter feit products? Journal of Business Strategy, 32 (2), 412.

Tom, G., Garibaldi, B., Zeng, Y. and Pilcher, J. (1998), "Consumer demand for counterfeit goods", Psychology \& Marketing, Vol. 15 No. 5, pp. 405-21.

Wang, F., Zhang, H., Zang, H. and Ouyang, M. (2005), "Purchasing pirated software: an initial examinationofChineseconsumers",JournalofConsumerMarketing,Vol.22No.6,pp.340-51.

Wee, C.H., Tan, S.J. and Cheok, K.H. (1995), "Non-price determinants of intention to purchase counterfeit goods: an exploratory study", International Marketing Review, Vol. 12 No. 6, pp. 19-46.

Wilcox, K., Kim, H.M. and Sen, S. (2009), "Why do consumers buy counterfeit luxury brands?”, Journal of Marketing Research, Vol. XLVI, pp. 247-59.

Yoo, B., \& Lee, SH. (2009). Buy genuine luxury fashion products or counterfeits? Advances in Consumer Research, 36, 280286. 